\title{
Pre-teens, Audio Analgesia and Dental Care: A Cross-Sectional Study
}

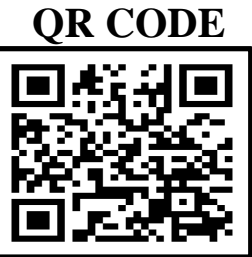

\section{AKSHAYE KUMAR', PRIYANKA SHARMA*2, ARJUN MALHOTRA'}

INTRODUCTION: Research has proven that music plays an important role in alleviating fear and anxiety among patients.

AIM: To assess the effect of audio analgesia in pre-teen children aged 8-12 years undergoing dental restorations.

MATERIALS AND METHOD: Data was collected using a pre-tested and pre-validated proforma filled by the child prior to start of the treatment by circling the number corresponding to the expected pain during the procedure [Ranged o (No pain) -10 (Maximum pain)]. Children who reported their expected pain above 5 , were enrolled in group 1 (The ones receiving audio analgesia) while the remaining were assigned group 2 (controls). Children in group 1 were asked to put on their favourite song using noise cancellation headphones and the procedure was commenced. After completion of the treatment, the VAS scale was re-introduced and the children were asked to re-circle the actual pain experienced during the procedure. Data was analyzed using SPSS version 20.0 using the chi-squared test and Pearson's correlation coefficient. A significant value was obtained when $\mathrm{p}$ was $\leq 0.05$.

RESULTS: Of the total 80 children enrolled in the present study, there were an equal number of males and females (40 each). It was observed that $70.3 \%$ of children in group 1 had an increased pain tolerance as compared to only $37.2 \%$ of children in the control group $(\mathrm{p}=0.01)$. Pearson's Correlation revealed a positive and linear association $(\mathrm{r}:+0.721)$ and a significant relationship $(\mathrm{p}=0.03)$ between both groups.

CONCLUSION: Audio analgesia has been proven to a promising alternative to distract the patient from the anxiety faced in the dental setting and is recommended for nervous and anxious patients.

KEYWORDS: Analgesia, Teens, Anxiety

\section{INTRODUCTION}

Visiting a dental office for treatment can become an unnecessary source of anxiety and nervousness for a few dental patients. One can describe dental anxiety as "an aversive emotional state of apprehension or worry in anticipation of the feared stimulus of dental treatment" and has been attributed to play a central role in the avoidance of dental treatment. ${ }^{1-3}$

High levels of dental fear have also been linked to poor oral health habits which, in turn increase the need for treatment and periodic checkups. ${ }^{4}$ The fear among children is even greater and there have been various techniques applied to distract the fear of the patient. In the field of medicine, distraction has been frequently used for pain management, interventions and research., 5

One such distraction technique is audio analgesia wherein the patient is distracted using some kind of audio, usually music of his/her choice and studies indicate that music reduces anxiety and improves psychological well-being. ${ }^{7}$ Hence, music finds itself as a potentially viable non-pharmacological treatment for alleviating pain in the medical, dental and related sciences. ${ }^{8}$

Due to the positive effects of audio analgesia, the present study was undertaken to assess the effect of audio analgesia in pre-teen children aged 8-12 years undergoing dental restoration.

\section{MATERIALS AND METHOD}

The present study was conducted amongst pre-teens aged 8-12 years in Nasik City, Maharashtra, India using convenience sampling from $\mathrm{Ol}^{\text {st }}$ May 2019 to $30^{\text {th }}$ November, 2019 after obtaining all necessary approvals (including ethical clearance) prior to start of the study.

Data was collected using a pre-tested and pre-validated proforma filled by the child prior to start of the treatment by circling the number corresponding to the expected pain. The ranges of VAS were from o-10 with $o$ indicating no pain and 10 including maximum pain. Only those students were enrolled in the study whose 
treatment protocol included restorations and the written consent of the parents was taken before treatment and after explaining the aims and objectives of the study.

Children who reported an expected pain above 5, were enrolled in group 1 (The ones receiving audio analgesia) while those reporting expected pain under 5 formed the controls. Children I group 1 were asked to put on their favourite song using noise cancellation headphones and the procedure was commenced.

After completion of the treatment, the VAS scale was re-introduced and the children and they were asked to circle the actual pain experienced during the procedure. Data was analyzed in SPSS Version 20.0 using the chisquared test and Pearson's correlation coefficient. A significant value was obtained when $\mathrm{p}$ was $\leq 0.05$.

\section{RESULTS}

\section{Description of Study Population (Figure 1)}

The study population is described in figure 1 . Of the total 80 children enrolled in the present study, there were an equal number of males $(40,50 \%)$ and females $(40,50 \%)$. There were 37 children in group 1 (those receiving audio analgesia) and 43 children in group 2 (control group).

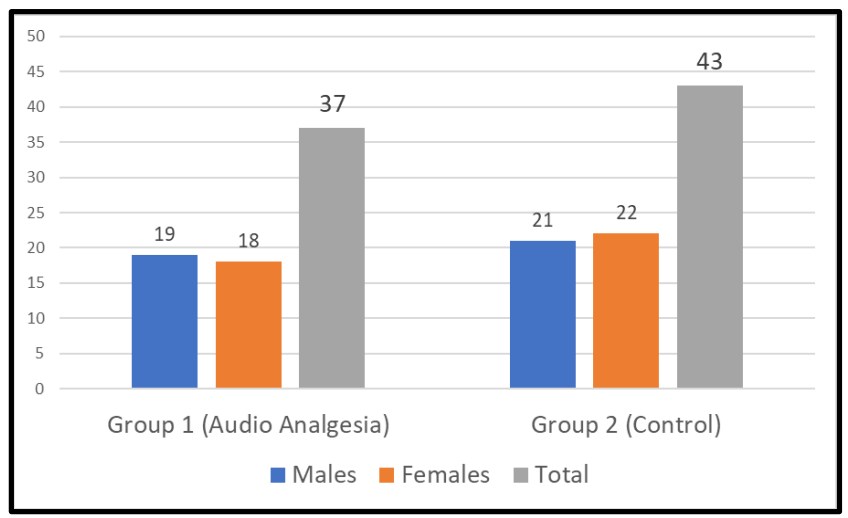

Figure 1. Gender Distribution of The Children Enrolled in The Present Study

\section{Effect of Audio Analgesia on Children (Table 1)}

It was observed that $70.3 \%$ of children in group 1 had an increased pain tolerance as compared to only $37.2 \%$ of children in the control group. The difference observed in pain tolerance in group 1 was also found to be significant upon comparison with the control group $(\mathrm{p}=0.01)$.

\begin{tabular}{|c|c|c|c|}
\hline Group & $\begin{array}{l}\text { Increased } \\
\text { Pain } \\
\text { Tolerance }\end{array}$ & $\begin{array}{c}\text { No } \\
\text { Change in } \\
\text { Pain } \\
\text { Tolerance }\end{array}$ & $\begin{array}{l}\text { P value } \\
\text { (From } \\
\text { Chi- } \\
\text { Squared } \\
\text { test) }\end{array}$ \\
\hline $\begin{array}{c}1 \text { (Audio } \\
\text { Analgesia) }\end{array}$ & $26(70.3 \%)$ & $11(29.7 \%)$ & $0.01^{*}$ \\
\hline $\begin{array}{l}2 \text { (Control } \\
\text { Group) }\end{array}$ & $16(37.2 \%)$ & $27(62.8 \%)$ & NS \\
\hline
\end{tabular}

Table 1. The effect of audio analgesia in children (NS: Non- Significant, * denotes a significant observation)

Relationship between Audio Analgesia and Increased Pain threshold (Table 2)

A positive, linear, great strength of association ( $\mathrm{r}$ : $+0.721)$ and a significant relationship $(\mathrm{p}=0.03)$ was found between use of audio analgesia and Increased pain threshold using Pearson's correlation coefficient.

\begin{tabular}{|c|c|c|c|}
\hline $\begin{array}{c}\text { Correlation } \\
\text { between }\end{array}$ & $\begin{array}{l}\text { Pearson's } \\
\text { Correlation } \\
\text { Coefficient }\end{array}$ & CI & p value \\
\hline $\begin{array}{c}\text { Audio } \\
\text { Analgesia* } \\
\text { Pain } \\
\text { threshold }\end{array}$ & +0.721 & $2.3-10.0$ & $0.03^{*}$ \\
\hline
\end{tabular}

Table 2. Correlation between knowledge, attitudes and practices using Pearson's correlation test (CI: Confidence Interval, * denotes a significant observation)

\section{DISCUSSION}

The results of the present study indicated that audio analgesia increased pain tolerance upto $70.3 \%$ in anxious children and it is supported by the case report of Bhagania, $\mathrm{M}$ et al. $(2011)^{10}$ wherein a 28 year old female patient chose devotional music in place of local anaesthesia and not show any subjective signs of pain or any pain behaviour during the extraction procedure.

The results of the present study are encouraging as the ultimate aim of dentists is to reduce fear and anxiety through behaviour management techniques and leave a positive attitude of the patient towards further dental care. ${ }^{11}$ We used the age group of 8-12 years as this age group can understand verbal commands correctly as well as communicate their feelings openly. This is supported by various authors who support the fact that behaviour management techniques should be used in children who can understand the situation, as different age groups exhibit different cognitive characteristics and behavioural pattern and hence, require different 
approaches towards each age group..$^{11,12}$

It was observed that although $70.3 \%$ of anxious patients exhibited increased pain tolerance, no child reported absence of pain. This is consistent with the findings of Marwah N et al.(2005) ${ }^{13}$, Who reported that audio distraction decreased the anxiety level in the pediatric patients, but not to a very significant level; Instrumental music was the music of choice and despite lack of any relief from pain, there was an overwhelming positive response to the music was requested by the patients in subsequent visits.

The choice of music played also has a very important role in alleviating anxiety of the patient. Various authors have left the choice of music to the patient, while others have not.13,14 The option to let the child choose the music was to gain control over the unpleasant stimulus and give them a sense of being in a familiar, safe and secure environment.

As author, we do not rule out the possibility of social desirability bias by the children and difference in pain perceptions among them. However, the results of the present study are generalizable and provide a further avenue for further trials on the use of audio distraction and fear alleviation in the dental patients.

\section{CONCLUSION}

Based on the results of the present study, the use of audio analgesia is recommended in patients, especially children with high anxiety levels. Also, we call for trials to further support or reject the use of audio analgesia in the dental setting.

\section{REFERENCES}

1. Armfield JM. How do we measure dental fear and what are we measuring anyway? Oral Health Prev Dent. 2010;8:107-115.

2. Armfield JM, Spencer AJ, Stewart JF. Dental fear in Australia: who's afraid of the dentist? Aust Dent J. 2006; $51(1): 78-85$. https://doi.org/10.1111/j.18347819.2006.tboo405.x.
3. Caltabiano ML, Crocker F, Page L, Sklavos A, Spiteri J, Hanrahan L, et al. Dental anxiety in patients attending a student dental clinic. BMC Oral Health. 2018; 18: 48. https://doi.org/10.1186/s12903-018-0507-5

4. Pohjola V, Rekola A, Kunttu K, Virtanen JI. Association between dental fear and oral health habits and treatment need among university students in Finland: a national study. BMC Oral Health. 2016;16:26. https://doi.org/10.1186/s12903-016-0179-y.

5. Cepeda MS, Carr DB, Lau J, Alvarez, H. Music for pain relief. Cochrane Database of Systematic Reviews. 2006; 2:CDoo4843. (Online)

6. Eccleston C. Role of psychology in pain management. British Journal of Anaesthesia. 2001;87(1):144-152.

7. Cadigan ME, Haldeman SM, McNamara ME, Noyes DA, Spadafora MA, Carroll DL. The effects of music on cardiac patients on bed rest. Progress in Cardiovascular Nursing. 2001;16(1):5-13.

8. Bradt J, Dileo C, Shim M. Music interventions for preoperative anxiety. The Cochrane Library. 2013.

9. IBM Corp. Released 2011. IBM SPSS Statistics for Windows, Version 20.0. Armonk, NY: IBM Corp.

10. Bhagania M, Agnihotry A. Extraction of a Grossly Decayed Tooth Without Local Anesthesia But With Audio Analgesia: A Case Report. Music \& Medicine 2011;3(4):280-2. https://doi.org/10.1177/1943862111414146 11. Barreiros D, de Oliveira DS, de Queiroz AM, da Silva RA, de Paula-Silva FW, Küchler EC. Audiovisual distraction methods for anxiety in children during dental treatment: A systematic review and metaanalysis. J Indian Soc Pedod Prev Dent. 2018;36:2-8. https://doi.org/10.4103/JISPPD.JISPPD_188_16

12. Asl Aminabadi N, Erfanparast L, Sohrabi A, Ghertasi Oskouei S, Naghili A. The impact of virtual reality distraction on pain and anxiety during dental treatment in 4-6 year-old children: A randomized controlled clinical trial. J Dent Res Dent Clin Dent Prospects. 2012;6:117-24.

13. Marwah N, Prabhakar A R, Raju OS. Music distraction - its efficacy in management of anxious pediatric dental patients. J Indian Soc Pedod Prev Dent. 2005;23:168-70. https://doi.org/10.4103/0970-4388.19003

14. Klein SA, Winkelstein ML. Enhancing pediatric health care with music. J Ped Health Care. 1996;10:7481. 
Cite this article as:

Kumar A, Sharma P, Malhotra A. Pre-teens, Audio Analgesia and Dental Care:

A Cross-Sectional Study. Int Healthc Res J. 2020;4(4):98-101.

Source of support: Nil, Conflict of interest: None declared

https://doi.org/10.26440/IHRJ/0404.07099

AUTHOR AFFILIATIONS: (*Corresponding Author)

1. MDS (Pedodontics and Preventive Dentistry)

2. MDS (Oral and Maxillofacial Pathology)

Sri Sai Dental Clinic and Centre, Nashik \& Pune, Maharashtra, India

Contact corresponding author at: akumaro102[at]yahoo[dot]in 